\title{
Cold-water coral habitats and canyons as Essential Fish Habitats in the southern Adriatic and northern Ionian Sea (central Mediterranean)
}

\author{
Francesca Capezzuto*, Letizia Sion, Francesco Ancona, Roberto Carlucci, Angela Carluccio, \\ Laura Cornacchia, Porzia Maiorano, Pasquale Ricci, Angelo Tursi, Gianfranco D'Onghia
}

\author{
Department of Biology, University of Bari Aldo Moro - Via Orabona 4, 70125 Bari \\ CoNISMa LRU of Bari University \\ *francesca.capezzuto@uniba.it
}

Received 29 April 2018/Accepted 19 June 2018.

\begin{abstract}
The objective of this study is to provide additional evidence of the utilization of Cold-Water Corals (CWC) and Submarine Canyons (SC) by fishes as areas for growing to maturity and to reproduce and thus for the classification of CWC as Essential Fish habitats (EFH). Data were collected with longline experimental surveys carried out during spring-summer and autumn-winter from 2010 to 2014, in different CWC sites distributed along the Apulian margin: Gondola Slide (GS), Bari Canyon (BC), Monopoli (Mn) and Santa Maria di Leuca (SML). In the present study the reproductive phase of Galeus melastomus, Conger conger, Helicolenus dactylopterus, Merluccius merluccius, Pagellus bogaraveo and Phycis blennoides collected in the abovementioned CWC communities has been analysed with respect to fish size. Maturing and mature individuals as well as post-reproductive specimens of G. melastomus, H. dactylopterus and M. merluccius were observed in all the investigated CWC sites. Mature gonads were also found in the other three species, although the investigated period was outside their reproductive peak, indicating that these CWC sites act as spawning areas and therefore as a potential 'renewal network' for fish species exploited in the neighbouring fishing grounds. This provides a strong argument for the categorization of CWC as EFH in the design of management programs.
\end{abstract}

Keywords: cold-water coral, canyon, essential fish habitat, Mediterranean

\section{Introduction}

Essential Fish Habitats (EFH) are bodies of waters and substrate required for fish spawning, breeding and feeding as well as a place they can grow to maturity (Rosenberg et al. 2000). According to the General Fisheries Commission for the Mediterranean (GFCM), EFH are defined as habitats identified as essential to the ecological and biological requirements for critical life history stages of exploited fish species, and which may require special protection to improve the conservation status of the stocks and their longterm sustainable exploitation (GFCM 2008).
Many studies have demonstrated that the structural complexity of the habitat plays a very important role in the life history of marine species both in shallow and deep waters (e.g. Pearcy et al. 1989; Sale 2002; Auster 2005; Caddy 2007 and references therein; Juanes 2007 and references therein; Buhl-Mortensen et al. 2010 and references therein; Miller et al. 2012; Ross et al. 2015; D’Onghia 2018).

In particular, heterogeneous and complex habitats, such as submarine canyons and cold-water coral reefs, host a high concentration of life forms to be identified as hotspots of biodiversity (Freiwald et al. 2004; Roberts et al. 2009; De Leo et al. 2010; Fernandez-Arcaya et al. 2017; 
Henry \& Roberts 2017). These types of habitats, due their structural, hydrological and biological complexity as well as their enhanced trophic resources, may represent suitable sites for many species which spend critical phases of their life cycles there feeding, growing to maturity, spawning, and as a nursery as well as sheltering from predators and adverse physical conditions (e.g. Brodeur 2001; Fosså et al. 2002; Reed 2002; Costello et al. 2005; Busby et al. 2006; Stone 2006; Etnoyer \& Warrenchuk 2007; Sulak et al. 2007; Quattrini et al. 2009; Baillon et al. 2012; Miller et al. 2012; Henry et al. 2013; Ross et al. 2015; D’Onghia 2018).

In the Mediterranean several Cold-Water Coral communities (CWC) (Freiwald et al. 2009) and more than 500 submarine canyons (SC) (Harris \& Whiteway, 2011) have been identified. Although in the last two decades there has been a growing number of studies on both $\mathrm{CWC}$ and SC throughout this basin (e.g. Cartes et al. 2004 and references therein; Freiwald et al. 2009; Würtz 2012 and references therein; Fernandez-Arcaya et al. 2017 and references therein; Grehan et al. 2017 and references therein), only recently research efforts, carried out by means of video systems and gears at low impact, provided new insights into the role of CWC and SC as fish habitats (Hebbeln et al. 2009; D'Onghia et al. 2010, 2011, 2012, 2015a, 2015b, 2016; Farrugio 2012; Bo et al. 2011, 2012, 2014, 2015; Fabri et al. 2014; Cau et al. 2017; Mastrototaro et al. 2017). However, only a few of these studies reveal a clear relationship between fishes and CWC and SC (e.g. D'Onghia et al 2010, 2016; Bo et al. 2015; Cau et al. 2017; Mastrototaro et al. 2017).

Considering that CWC and SC are impacted by commercial fishing (e.g. Roberts et al. 2000; Fosså et al. 2002; Hall-Spencer et al. 2002; Reed 2002; Grehan et al. 2005; Wheeler et al. 2005; Orejas et al. 2009; Buhl-Mortensen et al. 2010; Fabri et al. 2014; Savini et al. 2014; D’Onghia et al. 2017), the associations between fish and habitats for feeding, spawning and as a nursery are of utmost importance for the development of effective management and conservation measures (Rosenberg et al. 2000; Grehan et al. 2009, 2017). Unfortunately, the evidence of a functional role that would qualify CWC and SC as EFHs in support of their protection (Foley et al. 2010) is still lacking (Baillon et al. 2012).

The objective of this study is to provide additional evidence of the utilization of CWC and SC by fishes as areas for growing to maturity and to reproduce.

\section{Study area}

This study regards a belt of heterogeneous and topographically complex habitats distributed between the southwestern Adriatic and north-western Ionian on the Apulian continental margin (southern Italy, central Mediterranean) (Fig. 1). The north-westernmost geomorphic structures, that indent the outer shelf and slope, are represented by the Gondola Slide (GS), Bari Canyon (BC) and Dauno Seamount (off BC) (Minisini et al. 2006; Verdicchio \& Trincardi 2006; Ridenteet al. 2007). Among these structures, the $\mathrm{BC}$ is a complex morphological structure that cuts through the south-western Adriatic shelf from east to west. It is $10 \mathrm{~km}$ wide, $30 \mathrm{~km}$ long and ranges between 200 and $1700 \mathrm{~m}$ in depth. The BC is characterized by two main branches separated by a mounded relief, a slope-confined trough between 500 and $700 \mathrm{~m}$ in depth (Ridente et al. 2007; Trincardi et al. 2007). The BC hosts a diversified CWC community with sponges, serpulids, bryozoans and fishes (Freiwald et al 2009; Bo et al. 2012; Sanfilippo et al. 2013; Angeletti et al. 2014; D’Onghia et al. 2015a,b). Southward the BC, there is a CWC site off Monopoli (Mn), between 300 and $600 \mathrm{~m}$ in depth, characterized by the occurrence of Madrepora oculata (D'Onghia et al. 2016). Beyond the Otranto Channel, in the north-western Ionian, the slope at depths between 400 and $1100 \mathrm{~m}$ is characterized by coral-hardground and living coral mounds, which constitute the Santa Maria di Leuca (SML) CWC province (Savini and Corselli, 2010). This CWC province is the widest and deepest known deep-sea coral community in the Mediterranean (Freiwald et al. 2009; Corselli 2010; Savini et al. 2014; Bargain et al. 2017). Dead and living colonies of Madrepora oculata and Lophelia pertusa, together with other colonial and solitary CWC species, massive sponges and a high number of invertebrate and vertebrate species have been recorded between 350 and $1100 \mathrm{~m}$ in depth (Tursi et al. 2004; Longo et al. 2005; Taviani et al. 2005; Carlier et al. 2009; Bongiorni et al. 2010; D’Onghia et al. 2010, 2011; Mastrototaro et al. 2010).

\section{Material and methods}

\section{Sampling}

In order to investigate on the utilization of CWC and SC by fishes as areas for growing to maturity and to reproduce, a number of longline experimental surveys were carried out during spring-summer and autumn-winter from 2010 to 2014, according to the different abovementioned sites (GS, $\mathrm{BC}, \mathrm{Mn}$ and SML) distributed along the Apulian margin. In both investigated periods, the same number of stations (8) was randomly allocated in depth ranges where corals had been recorded (D'Onghia et al. 2016). The hauls were repeated in approximately the same locations in both springsummer and autumn-winter. A commercial fishing vessel was used. It was equipped with a $3 \mathrm{~km}$ monofilament longline with 500 hooks and snoods of $2.5 \mathrm{~m}$ in length. Sardina pilchardus was used as bait in all the study areas. 


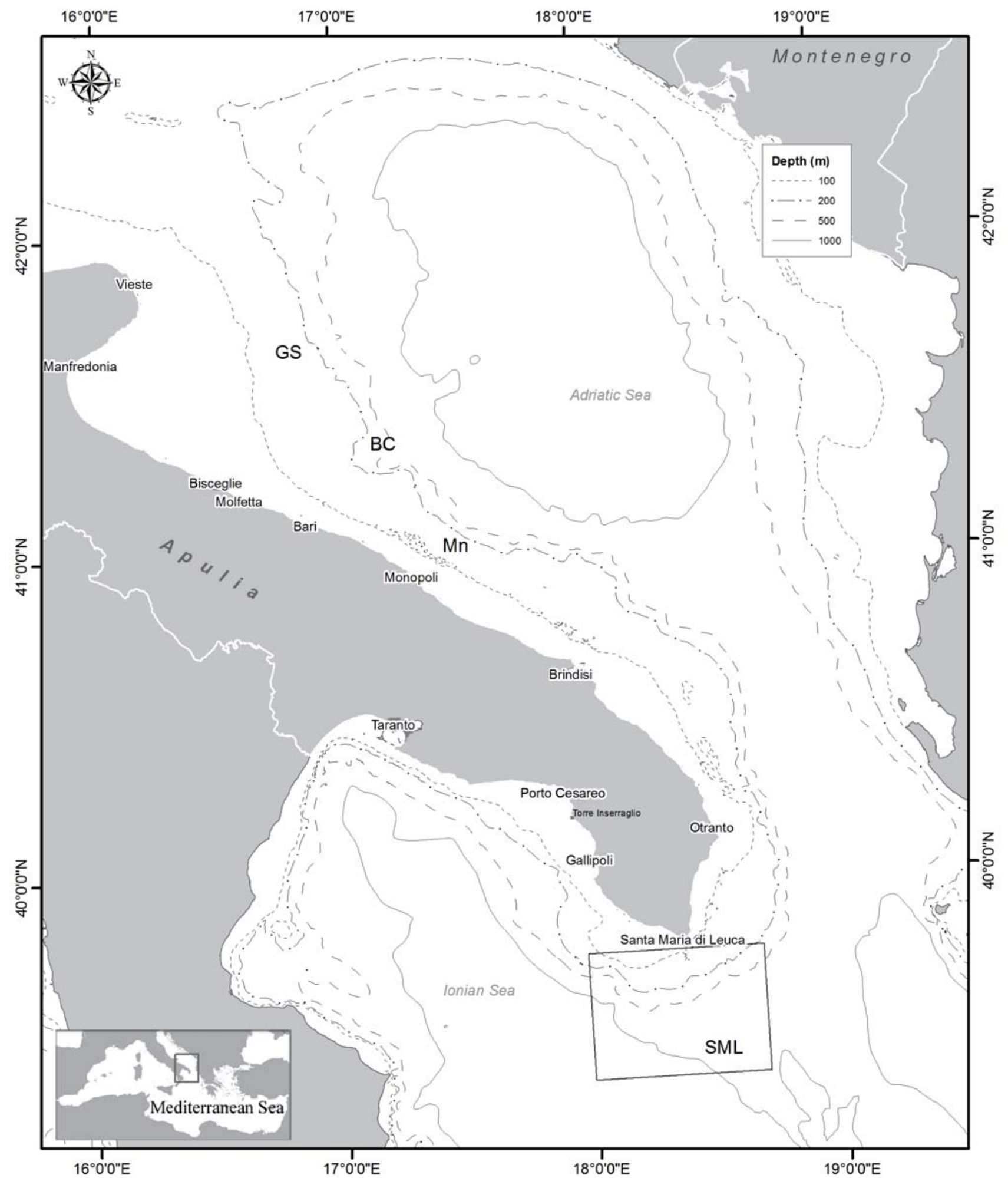

Figure 1. Cold-water coral communities investigated along the Apulian continental margin between the Southwestern Adriatic Sea and Northwestern Ionian Sea (Central Mediterranean). GS=Gondola Slide; BC=Bari Canyon; Mn=off Monopoli; SML=Santa Maria di Leuca cold-water coral (CWC) province 
The fishing hauls were carried out from dawn to dusk and the set time had a duration of approximately 3-4 hours for each haul. Data on the sampling for each season and depth range are reported in Table 1.

Table 1. Sampling data for each area and season, with indication of the depth range explored

\begin{tabular}{|c|c|c|c|}
\hline sea & area & season & $\begin{array}{c}\text { depth } \\
\text { range } \\
\text { (m) }\end{array}$ \\
\hline \multirow{5}{*}{$\begin{array}{l}\text { Southwestern } \\
\text { Adriatic }\end{array}$} & $\begin{array}{l}\text { Gondola Slide } \\
\text { (GS) }\end{array}$ & $\begin{array}{c}\text { spring-summer } \\
2014\end{array}$ & $183-432$ \\
\hline & \multirow{2}{*}{$\begin{array}{l}\text { Bari Canyon } \\
\text { (BC) }\end{array}$} & $\begin{array}{c}\text { autumn-winter } \\
2013\end{array}$ & $338-612$ \\
\hline & & $\begin{array}{c}\text { spring-summer } \\
2014\end{array}$ & $314-583$ \\
\hline & \multirow{2}{*}{ Monopoli (Mn) } & $\begin{array}{c}\text { autumn-winter } \\
2013\end{array}$ & $350-595$ \\
\hline & & $\begin{array}{l}\text { spring-summer } \\
2014\end{array}$ & $382-603$ \\
\hline \multirow{2}{*}{$\begin{array}{l}\text { Northwestern } \\
\text { Ionian }\end{array}$} & \multirow{2}{*}{$\begin{array}{l}\text { Santa Maria di } \\
\text { Leuca (SML) }\end{array}$} & $\begin{array}{l}\text { spring-summer } \\
2010\end{array}$ & $449-635$ \\
\hline & & $\begin{array}{c}\text { autumn-winter } \\
2010\end{array}$ & $455-599$ \\
\hline
\end{tabular}

\section{Data analysis}

For the most abundant fish species, those for which the number of individuals captured was greater than 10/1000 hooks in both sampling seasons and investigated areas as in D’Onghia et al. (2016) (Galeus melastomus, Conger conger, Helicolenus dactylopterus, Merluccius merluccius, Phycis blennoides, Pagellus bogaraveo), total length (TL, $\mathrm{mm}$ ) weight (g), sex and maturity stages were recorded for each specimen collected, following the modified Nikolsky's (1963) and Stehmann's (2002) macroscopic scales for Osteichthyes and Chondrichthyes, respectively. The features of the gonad in terms of size, shape, thickness and color were used to classify four main maturity stages: immature, maturing, mature and spent. For teleost fish the stages were: (i) immature (very small size, thin and ribbonlike translucent ovary and thin and whitish testis shorter than $1 / 3$ of the body cavity); (ii) maturing (thicker, whitish-pink in color ovary with small visible oocytes; whitish to creamy testis long about $2 / 3$ of the body cavity); (iii) mature (ovary with maximum thickness and weight full of oocytes of different sizes, many of which are hydrated; whitish-creamy soft testis long from $2 / 3$ to full length of the body cavity. Under light pressure, sperm could be expelled); (iv) spent (opaque and flaccid ovary, no oocyte clusters are visible with the naked eye; bloodshot and flab- by testis shrunken to about half length of the body cavity). For cartilaginous fish the stages were: (i) immature (ovary with small isodiametric eggs, thick oviductis, nidamental glands less evident; small and flaccid claspers not reaching the posterior edge of the pelvic fins, sperm ducts not differentiated and testis small and narrow); (ii) maturing (visible whitish and/or few yellow maturing eggs in the ovary, uteri well developed but empty, small nidamental glands; larger claspers with skeleton still flexible and extended to the posterior edge of the pelvic fins, sperm ducts well developed beginning to meander); (iii) mature (ovary with large yolk eggs, enlarged nidamental glands and presence/ absence of egg-cases in the oviducts; claspers longer than the tips of the posterior pelvic fin with ossified skeleton, testis greatly enlarged and sperm ducts greatly meandering, sperm flowing on pressure from cloaca); (iv) spent (oviducts appear much enlarged, collapsed and empty, nidamental glands reduced; claspers longer than the tips of the posterior pelvic fin, skeleton hardened, sperm ducts empty and flaccid).

A table for each species, each area and season with the percentage of two functional phases observed in the sampled population, a reproductive phase and a non-reproductive one, has also been provided, considering as "reproductive" all individuals with gonad stage maturing, mature and spent together. The length-frequency distributions by maturity stage were obtained for each species in the investigated areas, combining the two seasons. Images of maturing and/or mature stages were recorded.

\section{Results}

Relative percentages of reproductive and non-reproductive individuals for each species, area and season are reported in Table 2. The length-frequency distributions by maturity stage of the blackmouth catshark (Galeus melastomus), the European conger (Conger conger), the blackbelly rosefish (Helicolenus dactylopterus), the European hake (Merluccius merluccius), the blackspot seabream (Pagellus bogaraveo) and the greater forkbeard (Phycis blennoides) for each investigated area are reported in Fig. 2-3-4-5-6-7, respectively.

Most of the $G$. melastomus specimens sampled in the SML and BC were reproductive in both investigated seasons, due to its fairly continuous reproduction throughout the year (Tursi et al. 1993). Noteworthy percentages were also reported for $\mathrm{Mn}$ area, especially during spring-summer (Table 2). Considering length-frequency distributions in all areas, the observed range of sizes was between 225 and $684 \mathrm{~mm}$ TL. Immature individuals had sizes between 225 and $464 \mathrm{~mm}$ TL. Maturing and mature specimens measured from 295 to $525 \mathrm{~mm}$ and from 305 to $684 \mathrm{~mm}$, respectively. The smallest immature (305 $\mathrm{mm} \mathrm{TL}$ ) was re- 
corded in SML, the largest mature (676 mm TL) was collected in the BC (Fig. 2).

In the area of greatest abundance of $C$. Conger (SML), the highest percentages were observed for non-reproductive individuals, in both seasons (Table 2). The length-frequency distribution of the European conger was reported only for the BC and SML, due to the very low number of individuals collected in the other areas (Fig. 3). Even if in both investigated areas most of the captured specimens were immature, with sizes from 470 to $1219 \mathrm{~mm} \mathrm{TL}$, some gonads in the reproductive phase were observed, especially in SML. Maturing individuals measured between 710 and $1519 \mathrm{~mm}$ TL. The smallest mature individual was $677 \mathrm{~mm}$ in TL, while the largest was $1580 \mathrm{~mm}$ in TL, both recorded in SML. Both small and large individuals were also found for this species.

The highest percentages of reproductive individuals of H. dactylopterus were observed in the BC, Mn and SML areas during autumn-winter, coinciding with its main reproductive period (Muñoz et al. 2010). The highest value $(95.9 \%)$ was observed during this season in the BC. In the GS area, where the experimental survey was only conducted during spring-summer, noteworthy percentages of reproductive individuals were also observed, equal to $51.5 \%$ (Table 2). The length-frequency distribution of $H$. dactylopterus showed the smallest and the largest mature individual respectively equal to 176 and $380 \mathrm{~mm}$ TL, both collected in SML. Maturing specimens had sizes from 160 to $299 \mathrm{~mm}$ TL. Except for the Mn area, spent specimens were found in all the other investigated sites. The smallest individuals were collected in GS (Fig. 4) in relation to the ontogenetic migration of this species, with juveniles distributed in the shallower waters on muddy bottoms and adults at the greatest depths (D'Onghia et al. 1992).

Concerning $M$. merluccius, elevated percentages of reproductive individuals were found in all investigated areas and seasons, owing to the prolonged reproduction of this teleost fish (D'Onghia et al. 1995). The highest values were observed during spring in GS (88.9\%) and autumn in $\mathrm{BC}(83.8 \%)$ (Table 2). Considering all the areas, the observed range of sizes was between 311 and $829 \mathrm{~mm}$ TL (Fig. 5). In all the investigated areas maturing individuals were the most abundant, with sizes between 335 and $794 \mathrm{~mm}$ TL, observed respectively in the BC and SML. Three specimens with spent gonads were collected both in the $\mathrm{Mn}$ and SML areas. The smallest and largest mature
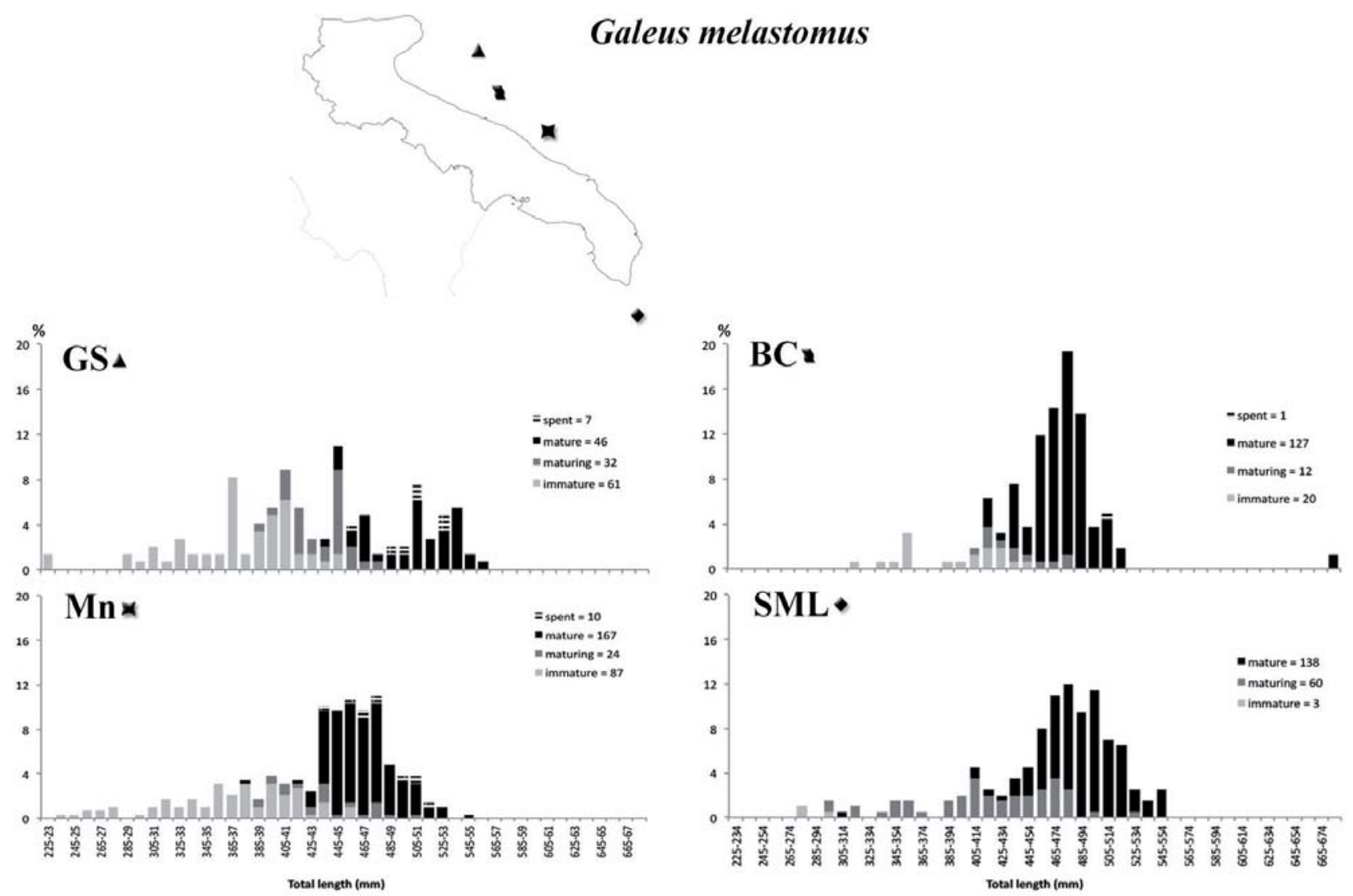

Figure 2. Length-frequency distributions by maturity stage of Galeus melastomus collected in the cold-water coral areas along the Apulian coast 


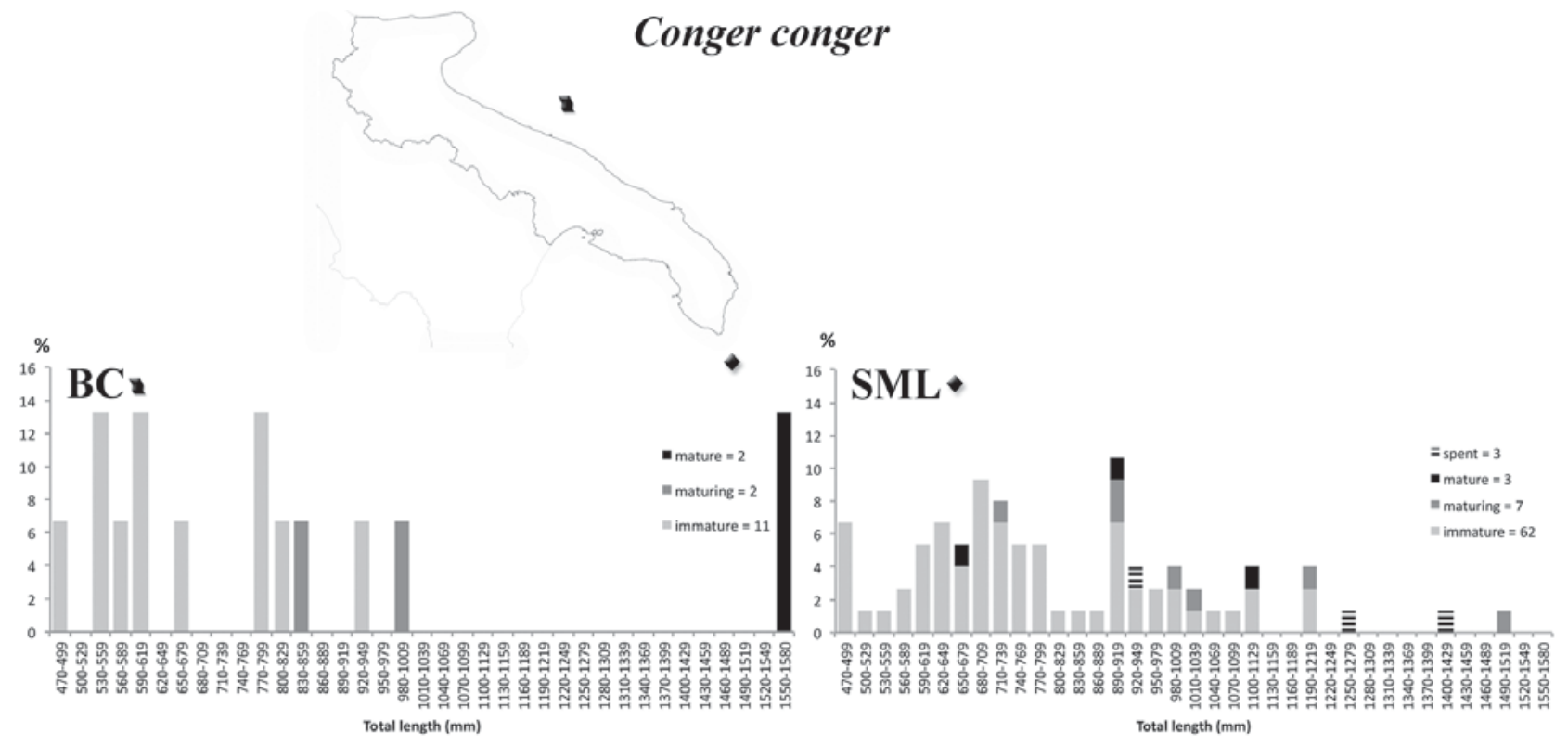

Figure 3. Length-frequency distributions by maturity stage of Conger conger collected in the cold-water coral areas along the Apulian coast

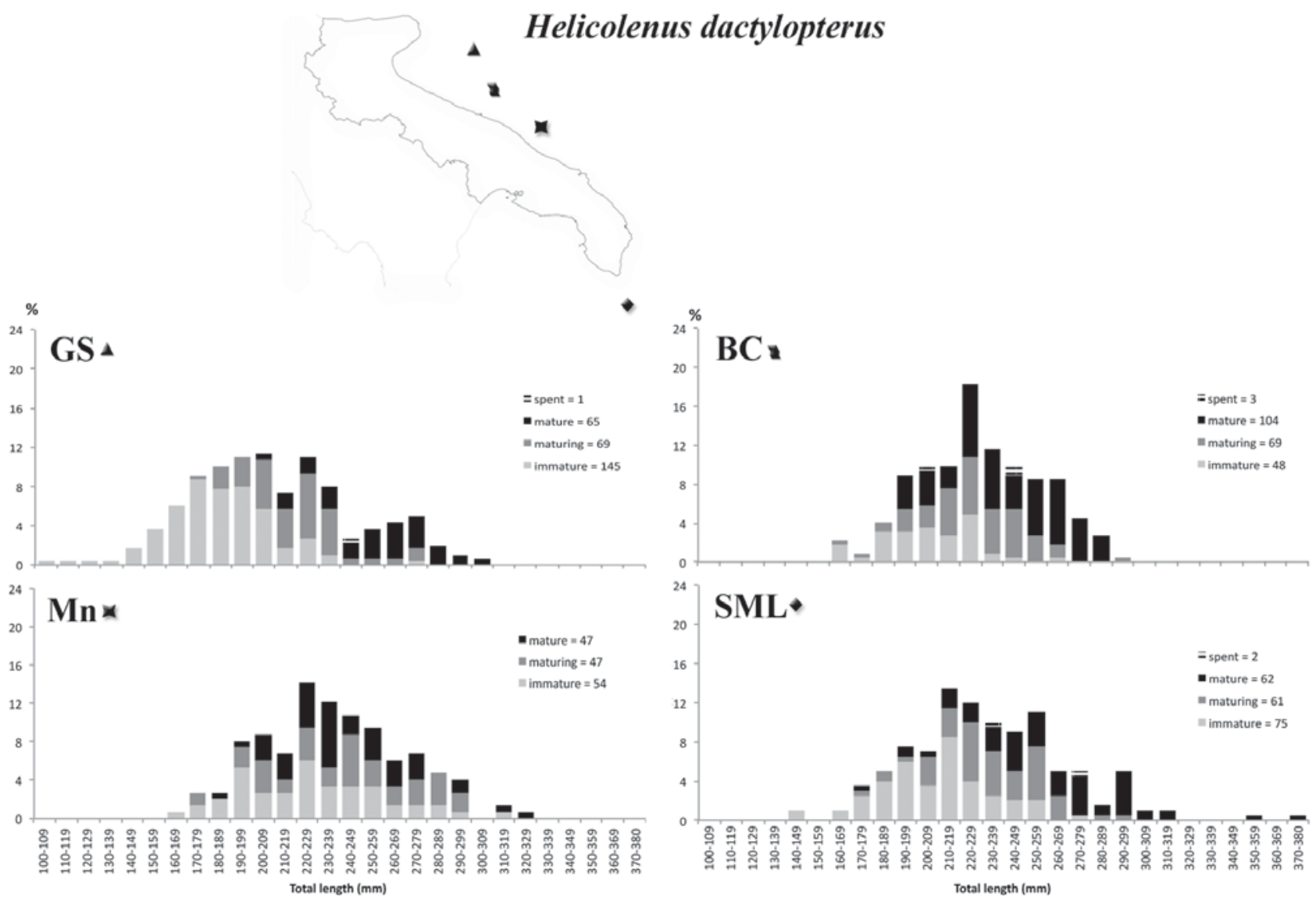

Figure 4. Length-frequency distributions by maturity stage of Helicolenus dactylopterus collected in the cold-water coral areas along the Apulian coast 
Table 2. Relative percentages of reproductive (r) and non-reproductive (nr) individuals by species, area and season

\begin{tabular}{|c|c|c|c|c|c|c|c|c|}
\hline & & \multirow{2}{*}{$\begin{array}{c}\text { GS } \\
\text { spring- } \\
\text { summer }\end{array}$} & \multicolumn{2}{|c|}{$\mathrm{BC}$} & \multicolumn{2}{|c|}{$\mathrm{Mn}$} & \multicolumn{2}{|c|}{ SML } \\
\hline & & & $\begin{array}{l}\text { spring- } \\
\text { summer }\end{array}$ & $\begin{array}{l}\text { autumn- } \\
\text { winter }\end{array}$ & $\begin{array}{l}\text { spring- } \\
\text { summer }\end{array}$ & $\begin{array}{l}\text { autumn- } \\
\text { winter }\end{array}$ & $\begin{array}{l}\text { spring- } \\
\text { summer }\end{array}$ & $\begin{array}{l}\text { autumn- } \\
\text { winter }\end{array}$ \\
\hline \multirow{2}{*}{$\begin{array}{l}\text { Galeus } \\
\text { melastomus }\end{array}$} & $\% \mathrm{r}$ & 58.2 & 85.3 & 88.1 & 77.5 & 62.7 & 98.3 & 98.8 \\
\hline & $\% \mathrm{nr}$ & 41.8 & 14.7 & 11.9 & 22.5 & 37.3 & 1.7 & 1.2 \\
\hline \multirow{2}{*}{$\begin{array}{l}\text { Conger } \\
\text { conger }\end{array}$} & $\% \mathrm{r}$ & - & 100.0 & 10.0 & 0.0 & - & 32.4 & 4.9 \\
\hline & $\% \mathrm{nr}$ & - & 0.0 & 90.0 & 100.0 & - & 67.6 & 95.1 \\
\hline \multirow{2}{*}{$\begin{array}{l}\text { Helicolenus } \\
\text { dactylopterus }\end{array}$} & $\% \mathrm{r}$ & 51.5 & 58.3 & 95.9 & 32.7 & 19.8 & 47.4 & 28.2 \\
\hline & $\% \mathrm{nr}$ & 48.5 & 41.7 & 4.1 & 67.3 & 80.2 & 52.6 & 71.8 \\
\hline \multirow{2}{*}{$\begin{array}{l}\text { Merluccius } \\
\text { merluccius }\end{array}$} & $\% \mathrm{r}$ & 88.9 & 77.8 & 83.8 & 62.9 & 70.0 & 71.0 & 60.0 \\
\hline & $\% \mathrm{nr}$ & 11.1 & 22.2 & 16.2 & 37.1 & 30.0 & 29.0 & 40.0 \\
\hline \multirow{2}{*}{$\begin{array}{l}\text { Pagellus } \\
\text { bogaraveo }\end{array}$} & $\% \mathrm{r}$ & 12.8 & 75.0 & 88.9 & 14.3 & 50.0 & 73.3 & 91.3 \\
\hline & $\% \mathrm{nr}$ & 87.2 & 25.0 & 11.1 & 85.7 & 50.0 & 26.7 & 8.7 \\
\hline \multirow{2}{*}{$\begin{array}{l}\text { Phycis } \\
\text { blennoides }\end{array}$} & $\% \mathrm{r}$ & 0.0 & 16.1 & 36.4 & 24.4 & 13.6 & 16.2 & 36.0 \\
\hline & $\% \mathrm{nr}$ & 100.0 & 83.9 & 63.6 & 75.6 & 86.4 & 83.8 & 64.0 \\
\hline
\end{tabular}

individuals of 349 and $810 \mathrm{~mm}$ TL respectively were collected in GS. Individuals of smaller sizes were found in all sites, except SML.

$P$. bogaraveo showed the highest percentages of reproductive gonads in both seasons in the $\mathrm{BC}$ and SML areas, even if with higher values during autumn-winter, respectively equal to $88.9 \%$ and $91.3 \%$. On the contrary, during spring-summer post-reproductive individuals were the most abundant in the GS and Mn areas. The lengthfrequency distributions of $P$. bogaraveo were only represented for GS, BC and SML, due to the low number of specimens sampled in the $\mathrm{Mn}$ area (Fig. 6). P. bogaraveo was collected with sizes between 185 and 404 mm TL. Immature and maturing specimens were between 185-405 and 225-404 mm TL, respectively. Mature specimens measured between 275 and $374 \mathrm{~mm}$ TL, both collected in the BC, even if the greatest size was also observed in SML.

Regarding $P$. blennoides, non-reproductive individuals were mostly recorded, especially during spring-summer (Table 2). This result was confirmed by the length-frequency distribution that showed, in the three areas where the species was found (BC, Mn, SML), the majority of the population consisted of immature individuals (Fig. 7). The observed size range was between 230 and $568 \mathrm{~mm}$ TL, respectively an immature and a maturing individual, with smaller specimens collected in all three areas. Maturing specimens had sizes between 320 and $569 \mathrm{~mm}$ TL. The four mature specimens collected measured between 440 and $539 \mathrm{~mm}$ TL. One post-reproductive specimen of 539 mm TL was observed in Mn.

Representative images of maturing and mature female and male gonads for each species and for the two areas of greatest abundance (BC, SML) are shown In Fig. 8.

\section{Discussion}

This study has provided additional evidence of the utilization of CWC and SC by fishes as areas for growing to maturity and reproduction. In the present study the reproductive phase of the most abundant species collected in a number of CWC communities have been analysed with respect to size. As reported in D'Onghia et al. (2016), these CWC sites are exposed to lower fishing pressure than neighbouring fishing grounds because of their complex topography. Thus, they can be considered refuge areas. The presence of maturing and mature individuals as well as post-reproductive specimens in all the CWC sites investigated, although with variable abundance in relation to the different spawning periods of the species and investigated depths, indicates that they also act as EFH.

Hebbeln et al. (2009), using a Remotely Operated Vehicle (ROV) in an area of the Alboran Sea (western Mediterranean), at about $320 \mathrm{~m}$ in depth, characterized by dead coral frameworks with live colonies of Madrepora oculata and Lophelia pertusa, and other CWC species, including 


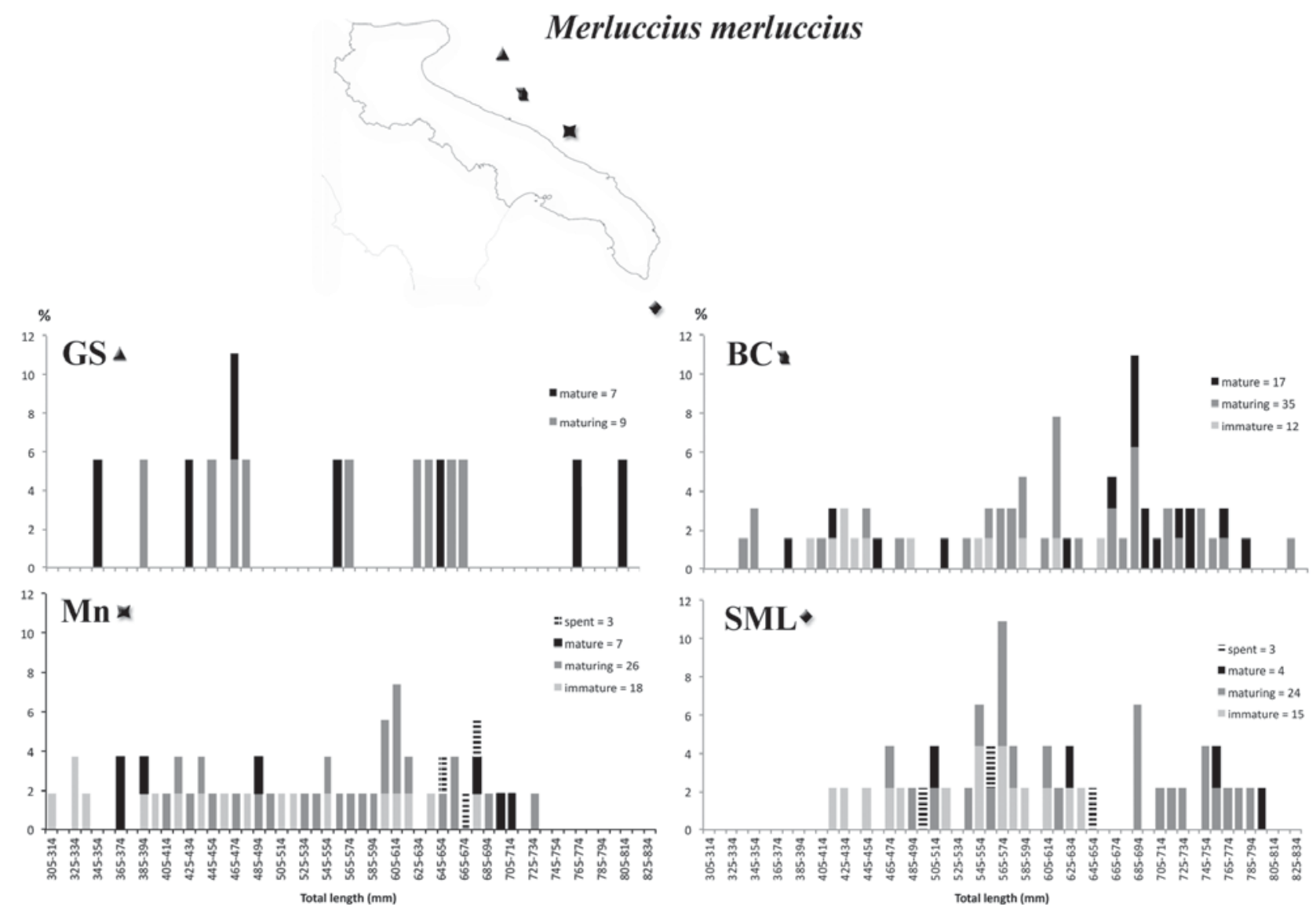

Figure 5. Length-frequency distributions by maturity stage of Merluccius merluccius collected in the cold-water coral areas along the Apulian coast
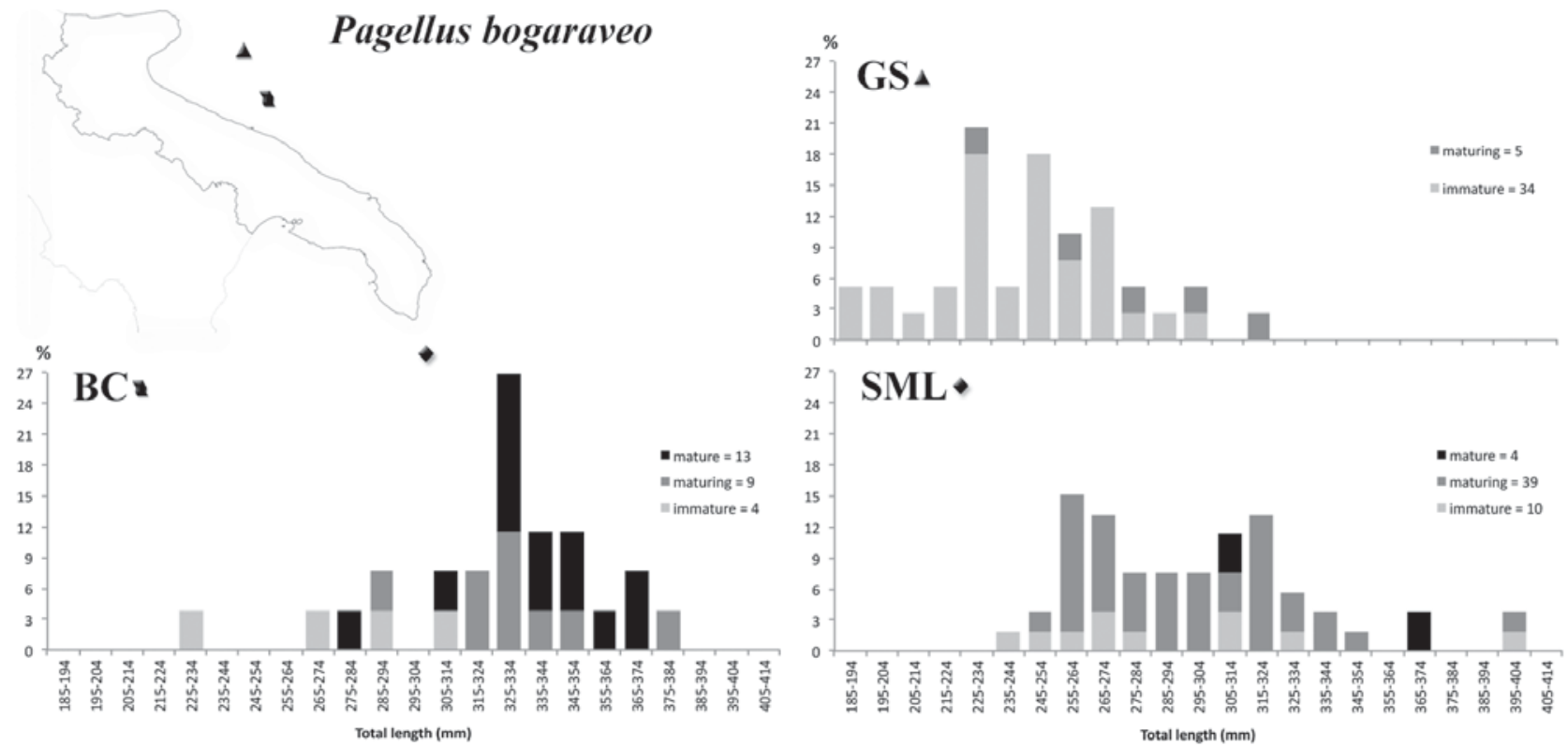

Figure 6. Length-frequency distributions by maturity stage of Pagellus bogaraveo collected in the cold-water coral areas along the Apulian coast 

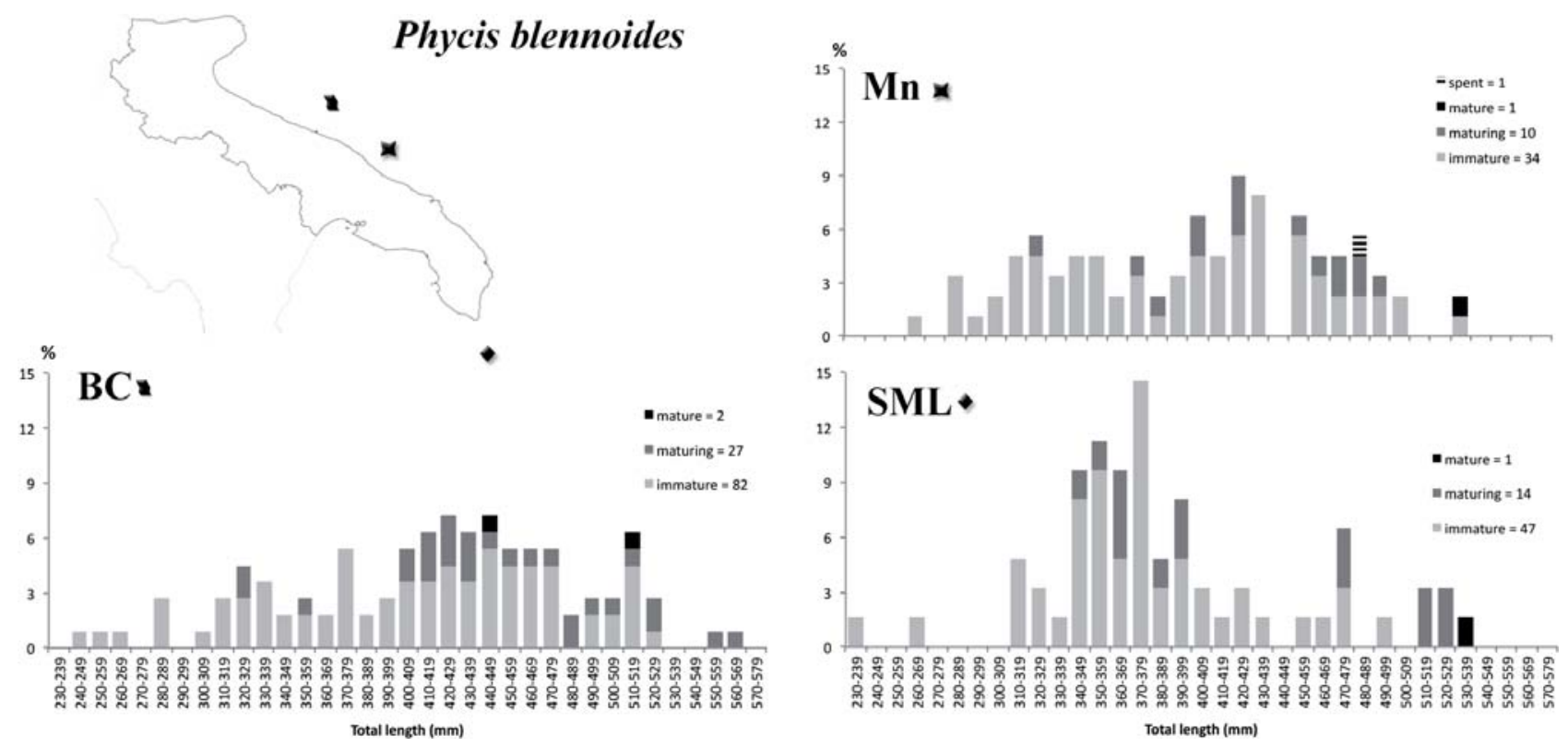

Figure 7. Length-frequency distributions by maturity stage of Phycis blennoides collected in the cold-water coral areas along the Apulian coast

gorgonians, black corals and sponges, observed several specimens of $H$. dactylopterus seek shelter close to and underneath coral colonies. Several other fish species, such as $P$. blennoides, $P$. bogaraveo and the lesser spotted dogfish (Scyliorhinus canicula), were also observed close to hardgrounds and coral frameworks with quite diverse epibenthic organisms (Hebbeln et al. 2009).

Large reproductive individuals of $G$. melastomus and $H$. dactylopterus and a noteworthy abundance of juveniles of $M$. merluccius, $P$. blennoides and $H$. dactylopterus had previously been collected in SML together with other species (D'Onghia et al. 2010). Further evidence of a tight relationship between $G$. melastomus, C. conger, $H$. dactylopterus and $P$. bogaraveo and $\mathrm{CWC}$ communities has been reported in other investigations with different gears and equipment (D'Onghia et al. 2011, 2012; Maiorano et al. 2013; Carluccio et al. 2014). Fernandez-Arcaya et al. (2013) report evidence of juveniles of some deep-sea fishes, like $P$. blennoides, in the Blanes canyon, which acts as a nursery area for these species. $H$. dactylopterus, $P$. bogaraveo and P. blennoides had been previously observed using a ROV in the Bari canyon (Angeletti et al. 2014). G. melastomus, H. dactylopterus, P. bogaraveo, P. blennoides, amongst other fish species, have been recorded in the Quirra and Nora canyons (Sardinian waters, western Mediterranean) (Sabatini et al. 2007; Taviani et al. 2017).

The species $G$. melastomus and $H$. dactylopterus were the most common fish species caught close to the black coral Leiopathes glaberrima and the gorgonian Isidella elongata in the eastern Ionian Sea (Mytilineou et al. 2014). H. dactylopterus was also found together with other fish species in black coral habitats dominated by L. glaberrima at the Malta Escarpment (Angeletti et al. 2015).

$G$. melastomus, $H$. dactylopterus, $M$. merluccius and $P$. blennoides among other species have also been observed on the muddy bottoms with Isidella elongata forests between two seamounts east of Ibiza (Balearic Sea) (Mastrototaro et al. 2017).

The same species reported in the present study were found sheltering, feeding and spawning in coral habitats and canyons in different Atlantic sites. For example, $H$. dactylopterus has been frequently recorded in different type of substrates both in canyons and in coral and transitional habitats (Uiblein et al. 2003; Costello et al. 2005; Ross \& Quattrini, 2007; Sulak et al. 2007; Ross et al. 2015; Milligan et al. 2016; D'Onghia 2018). The residency of sub-adult and adult of $P$. bogaraveo at the Condor seamount (Azores, mid-North Atlantic) was ascertained using acoustic telemetry (Afonso et al. 2012). G. melastomus has been observed on Lophelia reefs (Roberts et al. 2008; Duran Muñoz et al. 2009; Kutti et al. 2014). Egg cases of $G$. melastomus have been found nested in live L. pertusa corals at depths between 165 and $172 \mathrm{~m}$ in the Mingulay Reef Complex (Henry et al. 2013). C. conger has been observed as a large opportunistic predator living and foraging close to rocky areas where it finds refuge during the day (Morato et al. 1999; Xavier et al. 2010). Apart from G. melastomus, which has non-pelagic development, the fishes studied here have pelagic eggs and larval dispersal in the water masses. Both the spill-over effect and larval seeding might contribute to the renewal of stocks in neighboring fishing grounds. The particular water mass circulation between 


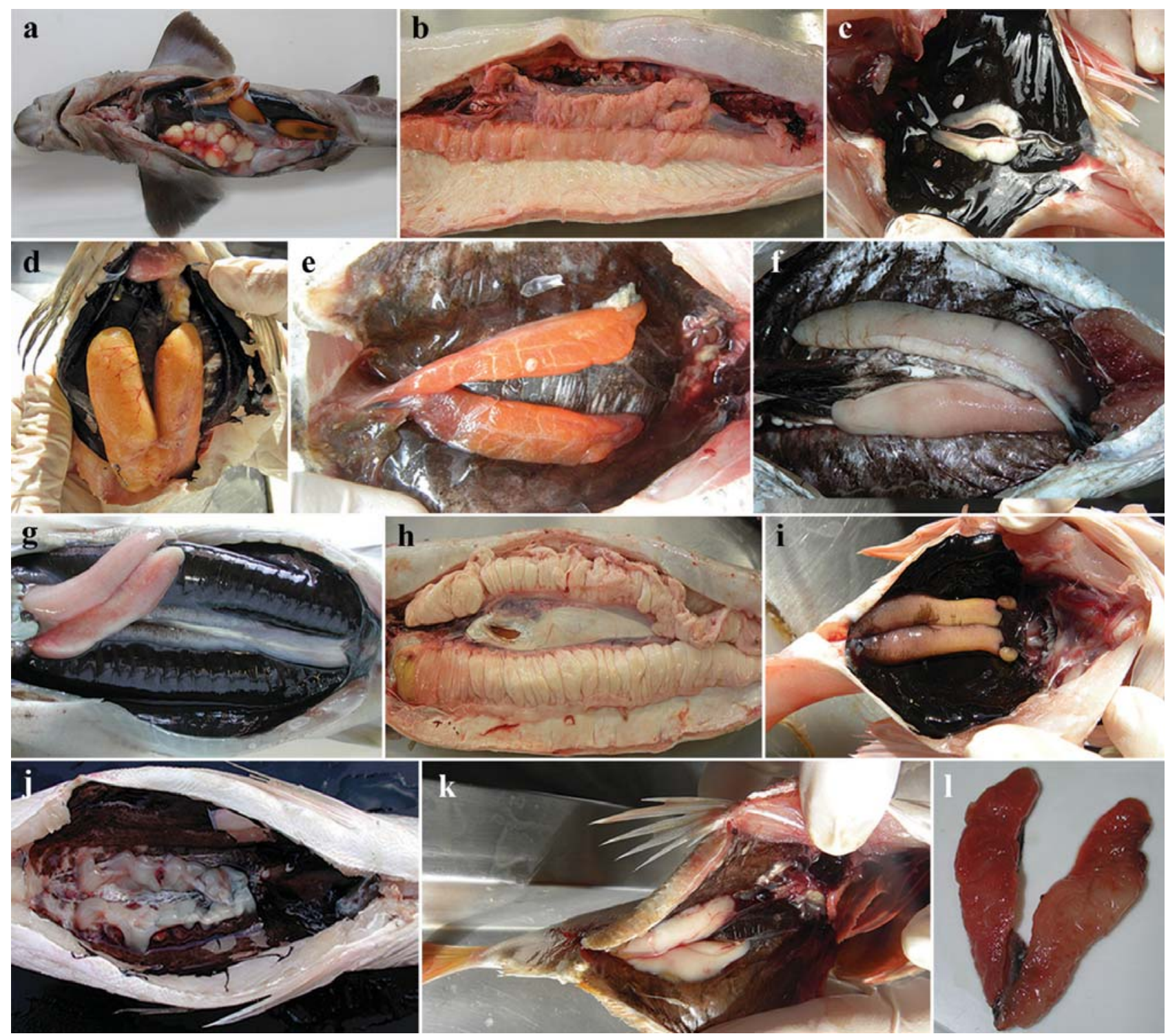

Figure 8. Representative images of maturing and mature female and male gonads for each species and for the two areas of greatest abundance, BC (a-f) and $\operatorname{SML}(\mathrm{g}-1)$. a): G. melastomus mature female; b) C. conger maturing female; c) H. dactylopteus mature male; d) M. merluccius mature female; e) P. bogaraveo mature female; f) P. blennoides mature male; g) G. melastomus mature male; h) C. conger mature female; i) H. dactylopterus mature female; j) M. merluccius mature male; k) P. bogaraveo mature male; 1) P. blennoides mature female

the southern Adriatic and northern Ionian (Freiwald et al. 2009; Taviani et al. 2017) seems to favour the transport of eggs and larvae from one CWC site to another including fished areas. Thus, CWC sites could act as marine reserves from which spill-over of individuals and larval seeding into adjacent fished areas has been documented (McClanahan \& Kaunda-Arara 1996; Roberts \& Hawkins 2000; Lowe et al. 2003; Hilborn et al. 2004).

Due to the complexity of their structure, CWC and SC are unsuitable for trawl fishing and only partly suitable for longline and other gears. Thus, many benthic and bentho- pelagic organisms can spend the critical phases of their life cycle, namely feeding, growing to maturity and spawning, there. In this way they reach greater biomass and size there than in exploited areas (e.g. Freiwald et al. 2004; Roberts et al. 2009; Buhl-Mortensen et al. 2010; D'Onghia et al. 2010; Baillon et al. 2012; Henry et al. 2013), becoming indirect providers of provisioning services in terms of food, for the commercial species. The importance of the role that CWC have in providing ecosystem services is even more important considering the overfishing condition of many demersal resources, such as $M$. merluccius, which is a spe- 
cies listed as Vulnerable on the Mediterranean IUCN Red List (Di Natale et al. 2011). Thus, a change in the environmental characteristics of these habitats, due to fishing, may have implications for service provision (Armstrong \& Falk-Petersen 2008; Armstrong et al. 2009).

Since corals may provide Essential Fish Habitats (EFH) for commercial fish and invertebrates and provide provisioning services, their protection could combine biodiversity conservation and fisheries management objectives according to the Ecosystem Approach to Fisheries (EAF) (Garcia et al. 2003). To date, apart from a Fisheries Restricted Area (FRA) established for SML (GFCM-RAC/ SPA 2007) and a proposal for a FRA recently made at the GFCM Sub-regional Committee for the Adriatic Sea held in Zagreb (GFCM 2018), no effective management measures have been established for other CWC sites along the Apulian margin. The present study highlights the role of these sites as EFH for several fish species and therefore the need for their protection and conservation, providing further data for the establishment of a representative network of Marine Protected Areas along the Apulian margin.

\section{References}

Afonso P., Graca G., Berke G. \& Fontes J., 2012, First observations on seamount habitat use of blackspot seabream (Pagellus bogaraveo) using acoustic telemetry, Journal of Experimental Marine Biology and Ecology 1(10): 436-437.

Angeletti L., Taviani M., Canese S., Foglini F., Mastrototaro F., Argnani A., Trincardi F., Bakran-Petricioli T., Ceregato A., Chimienti G., Macic V. \& Poliseno A., 2014, New deep-water cnidarian sites in the southern Adriatic Sea, Mediterranean Marine Science 15(2): 1-11.

Angeletti L., Mecho A., Doya C., Micallef A., Huvenne V., Georgiopoulou A. \& Taviani M., 2015, First report of live deep-water cnidarian assemblages from the Malta Escarpment, Italian Journal of Zoology 82(2): 291-297.

Armstrong C.W.\& Falk-Petersen J., 2008, Habitat fisheries interactions: A missing link? ICES Journal of Marine Science 65: 817-821.

Armstrong C.W., Grehan A.J., Kahui V., Mikkelsen E., Reithe S. \& van den Hove S., 2009, Bioeconomic modeling and the management of cold-water coral resources, Oceanography 22: 86-91.

Auster P.J., 2005, Are deep-water corals important habitats for fishes? [in]: Cold-Water Corals and Ecosystems, A. Freiwald, J.M. Roberts (eds), Springer, Berlin: 747-760.

Baillon S. Hamel J.-F., Wareham V.E. \& Mercier A., 2012, Deep cold-water corals as nurseries for fish larvae, Frontiers Ecology Environment 10(7): 351-356.

Bargain A., Marchese F., Savini A., Taviani M., \& Fabri M.C., 2017, Santa Maria di Leuca Province (Mediterra- nean Sea): Identification of Suitable Mounds for ColdWater Coral Settlement Using Geomorphometric Proxies and Maxent Methods, Frontiers in Marine Science, DOI: $10.3389 /$ fmars.2017.0033.

Bo M., Bavestrello G., Canese S., Giusti M., Angiolillo M., Cerrano C., Salvati E. \& Greco S., 2011, Coral assemblages off the Calabrian Coast (South Italy) with new observations on living colonies of Antipathes dichotoma, Italian Journal of Zoology 78: 231- 242

Bo M., Bertolino M., Bavestrello G., Canese S., Giusti M., Angiolillo M., Pansini M. \& Taviani M., 2012, Role of deep sponge grounds in the Mediterranean Sea: a case study in southern Italy, Hydrobiologia 687: 163-177.

Bo M., Bavestrello G., Angiolillo M., Calcagnile L., Canese S., Cannas R., Cau A., D'Elia M., D’Oriano F., Follesa M.C., Quarta G. \& Cau A., 2015, Persistence of Pristine Deep-Sea Coral Gardens in the Mediterranean Sea (SW Sardinia), PLoS ONE 10(3) e0119393.

Bo M., Cerrano C, Canese S., Salvati E., Angiolillo M., Santangelo G. \& Bavestrello G., 2014, The coral assemblages of an off-shore deep Mediterranean rocky bank (NW Sicily, Italy), Marine Ecology 35: 332-342.

Bongiorni L., Mea M., Gambi C., Pusceddu A., Taviani M. \& Danovaro R., 2010, Deep-water scleractinian corals promote higher biodiversity in deep-sea meiofaunal assemblages along continental margins, Biological Conservation 143: 1687-1700.

Brodeur R.D., 2001, Habitat-specific distribution of Pacific ocean perch (Sebastes alutus) in Pribilof Canyon, Bering Sea, Continental Shelf Research 21: 207-224.

Buhl-Mortensen L., Vanreusel A., Gooday A.J., Levin L.A., Priede I.G., Buhl-Mortensen P., Gheerardyn H., King N.J. \& Raes M., 2010, Biological structures as a source of habitat heterogeneity and biodiversity on the deep ocean margins, Marine Ecology 31: 21-50.

Busby M.S., Orr J.W. \& Blood D.M., 2006, Eggs and late-stage embryos of Allocareproctus unangas (family Liparidae) from the Aleutian Islands, Ichthyology Research 53: 423-426.

Caddy J.F., 2007, Marine habitat and cover: their importance for productive coastal fishery resources. UNESCO Publishing, Paris.

Carlier A., Le Guilloux E., Olu K., Sarrazin J., Mastrototaro F., Taviani M. \& Clavier J., 2009, Trophic relationships in a deep Mediterranean cold-water coral bank (Santa Maria di Leuca, Ionian Sea), Marine Ecology Progress Series 397: 125-137.

Carluccio A., Capezzuto F., Lionetti A., Ricci P. \& D’Onghia G., 2014, Refuge areas of Pagellus bogaraveo (Brünnich, 1768) in the central Mediterranean Sea: Santa Maria di Leuca cold-water coral province and Bari canyon, Biologia Marina Mediterranea 21(1): 214-215. 
Cartes J.E., Maynou F., Sardà F., Company J.B. LLori D. \& Tudela S., 2004, The Mediterranean deep-sea ecosystems: an overview of their diversity, structure, functioning and anthropogenic impacts with a proposal for conservation. WWF/ UICN, Rome and Málaga. part 1: $1-38$.

Cau A., Follesa M.C., Moccia D., Bellodi A., Mulas A., Bo M., Canese S., Angiolillo M., Cannas R., 2017, Leiopathes glaberrima millennial forest from SW Sardinia as nursery ground for the small spotted catshark Scyliorhinus canicula, Aquatic Conservation Marine Freshwater Ecosystems 27: 731-735.

Corselli C., 2010, The APLABES programme: physical, chemical and biological characterization of deep-water coral ecosystems from the Ionian Sea (Mediterranean), Deep-Sea Research II 57: 323-492.

Costello M.J., McCrea M., Freiwald A., Lundalv T., Jonsson L., Bett B.J., van Weering T.C.E., de Haas H., Roberts J.M. \& Allen D., 2005, Role of cold-water Lophelia pertusa coral reefs as fish habitat in the NE 116. [in]: Cold Water Coral and Ecosystems, A. Freiwald, J.M. Roberts (eds), Springer, Heidelberg: 771-805.

De Leo F.C., Smith C.R., Rowden A.A., Bowden D.A. \& Clark M.R., 2010, Submarine canyons: hotspots of benthic biomass and productivity in the deep sea,Proceedings of the Royal Society B, Biological Sciences 277: 2783-2792.

Di Natale A., Molinari A., Öztürk B., Srour A. \& Pollard D., 2011, Merluccius merluccius. The IUCN Red List of Threatened Species 2011. e.T198562A9031395. Downloaded on 26 March 2018.

D’Onghia G., 2018, Cold-Water Corals as Shelter, Feeding and Life-History Critical Habitats for Fish Species: Ecological Interactions and Fishing Impact, [in:] Orejas C, Jiménez (eds). Mediterranean Cold-Water Corals: Past, Present and Future. Springer. Chapter 30.

D’Onghia G., Calculli C., Capezzuto F., Carlucci R., Carluccio A., Grehan A., Indennidate A., Maiorano P., Mastrototaro F., Pollice A., Russo T., Savini A., Sion L. \& Tursi A., 2017, Anthropogenic impact in the Santa Maria di Leuca cold-water coral province (Mediterranean Sea): Observations and conservation straits, DeepSea Research II 145; 87-101.

D’Onghia G., Calculli E., Capezzuto F., Carlucci R., Carluccio A., Maiorano P., Pollice A., Ricci P., Sion L. \& Tursi A., 2016, New records of cold-water coral sites and fish fauna characterization of a potential network existing in the Mediterranean Sea, Marine Ecology 37: 1398-1422.

D’Onghia G., Capezzuto F., Cardone F., Carlucci R., Carluccio A., Chimienti G., Corriero G., Longo C., Maiorano P., Mastrototaro F., Panetta P., Rosso A., Sanfilippo R., Sion L. \& Tursi A., 2015a, Macro- and megafauna recorded in the submarine Bari Canyon (southern
Adriatic Sea, Mediterranean Sea) using different tools, Mediterranean Marine Science16(1): 180-196.

D’Onghia G., Capezzuto F., Carluccio A., Carlucci R., Giove A., Mastrototaro F., Panza M., Sion L., Tursi A. \& Maiorano P., 2015b, Exploring composition and behaviour of fish fauna by in situ observations in the Bari Canyon (Southern Adriatic Sea, Central Mediterranean), Marine Ecology 36: 541-556.

D’Onghia G., Indennidate A., Giove A., Savini A., Capezzuto F., Sion L., Vertino A. \& Maiorano P., 2011, Distribution and behaviour of the deep-sea benthopelagic fauna observed using towed cameras in the Santa Maria di Leuca cold water coral province, Marine Ecology Progress Series 443: 95-110.

D’Onghia G., Maiorano P., Carlucci R., Capezzuto F., Carluccio A., Tursi A. \& Sion L., 2012, Comparing deepsea fish fauna between coral and non-coral "megahabitat" in the Santa Maria di Leuca cold-water coral province (Mediterranean Sea), PLoS ONE 7(9), e44509.

D’Onghia G., Maiorano P., Sion L., Giove A., Capezzuto F., Carlucci R. \& Tursi A., 2010, Effects of deep-water coral banks on the abundance and size structure of the megafauna in the Mediterranean Sea, Deep-Sea Research II 57: 397-411.

D’Onghia G., Matarrese A. \& Tursi A., 1992, Biologia di Helicolenus dactylopterus (Delaroche, 1809): distribuzione e accrescimento sui fondi batiali del Mar Ionio, Oebalia suppl. XVII: 129-131.

D’Onghia G., Tursi A., Matarrese A. \& Sion L., 1995, Population dynamics of Merluccius merluccius (L., 1758) from the Ionian Sea (Mediterranean Sea), Annales de l'Institut Océanographique, Paris, 71: 35-44.

Duran Muñoz P., Sayago-Gi M., Cristobo J., Parra S., Serrano A., Diaz-del-Rio V., Patrocinio T., Sacau M., Murillo F.J., Palomino D. \& Fernandez-Salas L.M., 2009,Seabed mapping for selecting cold-water coral protection areas on Hatton Bank, Northeast Atlantic, ICES Journal of Marine Science 66: 2013-2025.

Etnoyer P. \& Warrenchuk, J., 2007, A catshark nursery in a deep Gorgonian field in the Mississippi Canyon, Gulf of Mexico, Bulletin of Marine Science 8: 553-559.

Fabri M.C., Pedel L., Beuck L., Galgani F., Hebbeln D. \& Freiwald A., 2014, Megafauna of vulnerable marine ecosystems in French Mediterranean submarine canyons: Spatial distribution and anthropogenic impacts, Deep-Sea Research II 104: 184-207.

Farrugio H., 2012, A refugium for the spawners of exploited Mediterranean marine species: the canyons of the continental slope of the Gulf of Lion. p. 45-49, [in:] Mediterranean Submarine Canyons: Ecology and Governance. M. Würtz (ed), IUCN: Gland, Switzerland and Málaga, Spain.

Fernandez-Arcaya U., Ramirez-Llodra E., Aguzzi J., Allcock A.L., Davies J.S., Dissanayake A., Harris P., How- 
ell K., Huvenne V.A.I., Macmillan-Lawler M., Martín J., Menot L., Nizinski M., Puig P., Rowden A.A., Sanchez F. \& Van den Beld I.M.J., 2017, Ecological Role of Submarine Canyons and Need for Canyon Conservation: A Review, Frontiers in Marine Science 4(5) doi: 10.3389/fmars.2017.00005.

Fernandez-Arcaya U., Rotllant G., Ramirez-Llodra E., Recasens L., Aguzzi J., Flexas M.D.M., Sanchez-Vidal A., López-Fernández P., García J.A. \& Company J.B., 2013, Reproductive biology and recruitment of the deep-sea fish community from the NW Mediterranean continental margin, Progress in Oceanography 118: 222-234

Foley N.S., Armstrong C.W. \& Rensburg van T.M., 2010, Estimating linkages between redfish and cold water coral on the Norwegian coast, Marine Resource Economics 25: 105-120.

Fosså J.H., Mortensen P.B. \& Furevik D.M., 2002, The deep-water coral Lophelia pertusa in Norwegian waters: distribution and fishery impacts, Hydrobiologia, 471: 1-12.

Freiwald A., Beuck L., Rüggerberg A., Taviani M. \& Hebblen D., 2009, The white coral community in the Central Mediterranean Sea revealed by ROV surveys, Oceanography 22(1): 36-52.

Freiwald A., Fossa J.H., Grehan A., Koslow T. \& Roberts J.M., 2004, Coldwater coral reefs. Out of sight no longer out of mind. UNEP-WCMC, Cambridge, UK.

Garcia S.M., Zerbi A., Aliaume C., Do Chi T. \& Lasserre G., 2003, The ecosystem approach to fisheries. Issue, terminology, principles, institutional foundations, implementation and outlook, FAO Fisheries Technical Paper 443 FAO, Rome: 71.

GFCM-RAC/SPA, 2007, Report of the Transversal Workshop on Marine Protected Areas (MPAs). Salammbô, Tunisia, pp. 34

GFCM, S.A.C., 2008, Criteria for the identification of sensitive habitats of relevance for the management of priority species, General Fisheries Commission for the Mediterranean-Scientific Advisory Committee-SubCommittee on Marine Environment and Ecosystems (SCMEE), Marrakech, Marocco.

GFCM, 2018, Workshop on the assessment of management scenarios for Mediterranean case studies, including ad hoc session for small pelagic species in the Adriatic Sea; Subregional Committee for the Adriatic Sea (SRCAS), Zagabria, Croazia.

Grehan A.J., Unnithan V., Olu-Le Roy K. \& Opderbecke J., 2005, Fishing impacts on deep-water coral reefs: making a case for coral conservation, [in:] Benthic Habitats and the Effects of Fishing, P.W. Barnesm \& J.P. Thomas (eds), American Fisheries Society, Bethesda, MD: 819-832.
Grehan A.J., Van den Hove S., Armstrong C.W., Long R., Van Rensburg T.V., Gunn V., Mikkelsen E., De Mol B. \& Hain S., 2009, HERMES promoting ecosystembased management and the sustainable use and governance of deep-water resources, Oceanography, 22: 154-165.

Grehan A.J, Arnaud-Haond S., D’Onghia G., Savini A. \& Yesson C., 2017, Towards ecosystem based management and monitoring of the deep Mediterranean, NorthEast Atlantic and Beyond, Deep-Sea Research Part II 145: 1-7.

Hall-Spencer J., Allain V. \& Fosså J.H., 2002, Trawling damage to northeast Atlantic ancient coral reefs, Proceedings of The Royal Society of London, Series BBiological Sciences 269: 507-511.

Harris P.T. \& Whiteway T., 2011, Global distribution of large submarine canyons: Geomorphic differences between active and passive continental margins, Marine Geology 285: 69-86.

Hebbeln D., Wienberg C., Beuck L., Freiwald A. \& Wintersteller P., cruise participants, 2009. Report and preliminary results of RV POSEIDON cruise POS 385 "coldwater corals of the Alboran Sea (western Mediterranean Sea)", Faro-Toulon, May 29-June 162009. Reports of the Department of Geosciences. University of Bremen (No. 273, 79 pp.).

Henry L.A., Navas J.M., Hennige S.J., Wick, L.C., Va, J. \& Murray Roberts J., 2013, Cold- water coral reef habitats benefit recreationally valuable sharks, Biological Conservation 161: 67-70.

Henry L.A., Roberts J.M., 2017, Global biodiversity in cold-water coral reefs, [in:] Marine animal forests, S. Rossi, L. Bramanti, A. Gori\&C. Orejas (eds), Switzerland: Springer, Cham: 235-256.

Hilborn R., Stokes K., Maguire J.J., Smith T., Botsford L.W., Mangel M., Orensanz J., Parma A., Rice J., Bell J., Cochrane K.L., Garcia S., Hall S.J., Kirkwood G.P., Sainsbury K., Stefansson G. \& Walters C., 2004, When can marine reserves improve fisheries management?, Ocean \& Coastal Management 47( 3-4): 197-205.

Juanes F., 2007, Role of habitat in mediating mortality during the post-settlement transition phase of temperate marine fishes, Journal of Fish Biology 70: 661-677.

Kutti T., Bergstad O.A., Fossa J.H. \& Helle K., 2014,Coldwater corals mound and sponge-beds as habitats for demersal fish on the Norwegian shelf. Deep Sea Research II 99, 122-133.

Longo C., Mastrototaro F. \& Corriero G., 2005, Sponge fauna associated with a Mediterranean white coral bank, Journal of the Marine Biological Association of the United Kingdom 85: 1341-1352.

Lowe C.G., Topping D.T., Cartamil D.P. \& Papastamatiou Y.P., 2003, Movement patterns, home range, and habitat utilization of adult kelp bass Paralabrax clathratus 
in a temperate no-take marine reserve, Marine Ecology Progress Series 256: 205-216.

Maiorano P., Sion L., Capezzuto F., Carlucci R., Mastrototaro F., Panza M., Tursi A. \& D’Onghia G., 2013, Exploring deep-sea benthopelagic fauna using a baited lander in the Santa Maria di Leuca cold water coral province, Rapport Commission International Mer Mediterranee 40: 719.

Mastrototaro F., Chimienti G., Acosta J., Blanco J., Garcia S., Rivera J. \& Aguilar R., 2017, Isidella elongata (Cnidaria: Alcyonacea) facies in the western Mediterranean Sea: visual surveys and descriptions of its ecological role, The European Zoological Journal 84(1): 209-225.

Mastrototaro F., D’Onghia G., Corriero G., Matarrese A., Maiorano P., Panetta P., Gherardi M., Longo C., Rosso A., Sciuto F., Sanfilippo R., Gravili C., Boero F., Taviani M. \& Tursi A., 2010, Biodiversity of the white coral bank off Cape Santa Maria di Leuca (Mediterranean Sea): An update, Deep-Sea Research II 57: 412-430.

McClanahan T.R. \& Kaunda-Arara B., 1996, Fishery recovery in a coral-reef marine park and its effect on the adjacent fishery, Conservation Biology 10(4): 11871199.

Miller R.J., Hoceva, J., Stone R.P. \& Fedorov D.V., 2012, Structure-forming corals and sponges and their use as fish habitat in Bering Sea submarine canyons, PLoS ONE 7(3), e33885.

Milligan R.J., Spence G., Roberts J.M. \& Bailey D.M., 2016, Standardized Abundances of Fish Observed in and Around Cold-water Corals in the North-east Atlantic From Remotely Operated Vehicle (Rov), Observations Made During Cruise JC073. British Oceanographic Data Centre - Natural Environment Research Council, UK.

Minisini D., Trincardi F. \& Asioli A., 2006, Evidence of slope instability in the South-Western Adriatic margin, Natural Hazards and Earth System Sciences, 6: 1-20.

Morato T., Sola E., Gros M.P. \& Menezes G., 1999,Diets of forkbeard (Phycis phycis) and conger eel (Conger conger) off the Azores during spring of 1996 and 1997, Arquipelago, Life Marine Sciences 17A: 51-64.

Muñoz M., Dimitriadis C., Casadevall M., Vila S., Delgado E., Lloret J. \& Saborido-Rey F., 2010, Female reproductive biology of the bluemouth Helicolenus dactylopterus dactylopterus: spawning and fecundity, Journal of Fish Biology 77: 2423-2442.

Mytilineou C., Smith C.J., Anastasopoulou A., Papadopoulou K.N., Christidis G., Bekas P., Kavadas S. \& DokosJ., 2014, New cold-water coral occurrences in the Eastern Ionian Sea: Results from experimental long line fishing, Deep Sea Reseerch II 99: 145-157.

Nikolsky G.V., 1963, The Ecology of Fishes. Academic Press, London, 352 pp.
Orejas C., Gori A., Lo Iacono C., Puig P., Gili J.M. \& Dale M.R.T., 2009, Cold-water corals in the Cap de Creus canyon, northwestern Mediterranean: spatial distribution, density and anthropogenic impact, Marine Ecology Progress Series 397: 37-51.

Pearcy W.G., Stein D.L., Hixon M.A., Pikitch E.K., Barss W.H. \& Starr R.M., 1989, Submersible Observations of Deep-Reef Fish of Heceta Bank, Oregon, Fishery Bulletin 87: 955-965.

Quattrini A.M., Partyka M.L. \& Ross S.W., 2009, Aspects of the reproductive biology of the skate Fenestraja plutonia (Garman) off North Carolina, Southeastern Naturalist8: $55-70$.

Reed J.K., 2002, Deep-water Oculina coral reefs of Florida: biology, impacts, and management, Hydrobiologia 471: 43-55.

Ridente D., Minisini D., Trincardi F. \& Verdicchio G., 2007, The onset of the Bari Canyon System on the South-Western Adriatic Margin, Central Mediterranean, Marine Geology 246: 193-207.

Roberts J.M., Harvey S.M., Lamont P.A. \& Gage J.D., 2000, Seabed photography, environmental assessment and evidence for deep-water trawling on the continental margin west of the Hebrides, Hydrobiologia 44: 173183.

Roberts C.M. \& Hawkins J.P., 2000, Fully-protected marine reserves: a guide, Washington, DC and University of York, UK: WWF Endangered Seas Campaign.

Roberts J.M., Henry L.A., Long D. \& Hartley J.P., 2008, Coldwater coral reef frameworks, megafaunal communities and evidence for coral carbonate mounds on the Hatton Bank, north east Atlantic, Facies 54: 297-316.

Roberts J.M., Wheeler A.J., Freiwald A. \& Cairns S.D., 2009, Cold-water corals: the biology and geology of deep-seacoral habitats. Cambridge University Press, New York, 334 pp.

Rosenberg A., Bigford T.E., Leathery S., Hill R.L. \& Bickers K., 2000, Ecosystem approaches to fishery management through essential fish habitat, Bulletin of marine science 66(3): 535-542.

Ross S.W. \& Quattrini A.M., 2007, The fish fauna associated with deep coral banks off the southeastern United States,Deep-Sea Research I 54: 975-1007.

Ross S.W., Rhode M. \& Quattrini A.M., 2015, Demersal fish distribution and habitat use within and near Baltimore and Norfolk Canyons, U.S. middle Atlantic slope, Deep-Sea Research I 103: 137-154.

Sabatini A., Follesa M.C., Locci I., Pendugiu A.A., Pesci P. \& Cau A., 2007, Assemblages in a submarine canyon: influence of depth and time. Hydrobiologia 580: 265-271.

Sale P.F., 2002, Coral Reef Fishes, Dynamics and Diversity in a Complex Ecosystem. Academic Press, San Diego, California. 
Sanfilippo R., Vertino A., Rosso A., Beuck L., Freiwald A. \& Taviani M., 2013, Serpula aggregates and their role in deep-sea coral communities in the southern Adriatic Sea, Facies 59(4): 663-677.

Savini A. \& Corselli C., 2010, High resolution bathymetry and acoustic geophysical data from Santa Maria di Leuca cold water coral province (northern Ionian Sea-Apulian continental slope), Deep-Sea Research II 57(5-6): 326-344.

Savini A., Vertino A., Marchese F., Beuck L. \& Freiwald A., 2014, Mapping cold-water coral habitats at different scales within the northern Ionian Sea (central Mediterranean): an assessment of coral coverage and associated vulnerability, PloS ONE 9(1), e87108.

Stehmann M.F.W., 2002, Proposal of a maturity stages scale for oviparous and viviparous cartilaginous fishes (Pisces, Chondrichthyes), Archive of Fishery and Marine Research 50: 23-48.

Stone R.P., 2006, Coral habitat in the Aleutian Islands of Alaska: depth distribution, fine-scale species associations, and fisheries interactions, Coral Reefs 25: 229238.

Sulak K.J., Brooks R.A., Luke K.E., Norem A.D., Randall M.T., Quaid A.J., Yeargin G.E., Miller J.M., Harden W.M., Caruso J.H. \& Ross S.W., 2007, Demersal fishes associated with Lophelia pertusa coral and hard-substrate biotopes on the Continental Slope, Northern Gulf of Mexico, [in:] Conservation and Adaptive Management of Seamount and Deep-Sea Coral Ecosystems, R.Y. George, S.D. Cairns (eds), University of Miami, Miami: 65-92.

Taviani M., Angeletti L., Canese S., Cannas R., Cardone F., Cau A., Cau A.B., Follesa M.C., Marchese F., Montagna P. \& Tessarolo C., 2017, The "Sardinian cold-water coral province" in the context of the Mediterranean coral ecosystems, Deep-Sea Research II 145: 61-78.

Taviani M., Remia A., Corselli C., Freiwald A., Malinverno E., Mastrototaro F., Taviani M., Freiwald A. \& Zibrowius H., 2005, Deep coral growth in the Mediterranean Sea: An overview, [in:] Cold Water Corals and
Ecosystems. A. Freiwald \& Roberts J.M. (eds), Springer, Heildelberg: 137-156.

Trincardi F., Foglini F., Verdicchio G., Asioli A., Corregiari A., Minisini D., Piva A., Remia A., Ridente D. \& Taviani M., 2007, The impact of cascading currents on the Bari Canyon System, SW-Adriatic Margin (Central Mediterranean), Marine Geology 246: 208-230.

Tursi A., D’Onghia G., Matarrese A. \& Piscitelli G., 1993, Observations on population biology of the Blackmouth catshark Galeus melastomus (Chondrichthyes, Scyliorhinidae) in the Ionian Sea, Cybium, 17: 187-196.

Tursi A., Mastrototaro F., Matarrese A., Maiorano P. \& D'Onghia G., 2004, Biodiversity of the white coral reefs in the Ionian Sea (Central Mediterranean), Chemical Ecology, 20: 107-116.

Uiblein F., Lorance P. \& Latrouite D., 2003, Behaviour and habitat utilization of seven demersal fish species on the Bay of Biscay continental slope, NE Atlantic, Marine Ecology Progress Series 257: 223-232.

Verdicchio G. \& Trincardi F., 2006, Short-distance variability in slope bed-forms along the Southwestern Adriatic Margin (Central Mediterranean), Marine Geology 234: 271-292.

Wheeler A.J., Kozachenko M., Beyer A., Foubert A., Huvenne V.A.I., Klages M., Masson D.G., Olu-Le Roy K. \& Thiede J., 2005, Sedimentary processes and carbonate mounds in the Belgica mound province, Porcupine Seabight, NE Atlantic, [in:] Cold-Water Corals and Ecosystems, A. Freiwald \& J.M. Roberts (eds), Springer, Heidelberg: 571-603.

Würtz M., 2012, Submarine canyons and their role in the Mediterranean ecosystem, [in:] Mediterranean Submarine Canyons: Ecology and Governance, M. Würtz (ed). IUCN: Gland, Switzerland and Málaga, Spain: 11-26.

Xavier J.C., Cherel Y., Assis C.A., Sendão J. \& Borges T., 2010, Feeding ecology of conger eels (Conger conger) in north-east Atlantic waters, Journal of the Marine Biological Association of the United Kingdom 90(3): 493-501. 